Chapman University

Chapman University Digital Commons

Food Science Faculty Articles and Research

Science and Technology Faculty Articles and

Research

$10-24-2018$

\title{
Identification of Shark Species in Commercial Products using DNA Barcoding
}

Rosalee S. Hellberg

Chapman University, hellberg@chapman.edu

Rachel B. Isaacs

Chapman University

Eduardo L. Hernandez

Chapman University

Follow this and additional works at: https://digitalcommons.chapman.edu/food_science_articles

Part of the Aquaculture and Fisheries Commons, Food Chemistry Commons, Marine Biology $\underline{\text { Commons, }} \underline{\text { Meat Science Commons, and the Other Food Science Commons }}$

\section{Recommended Citation}

Hellberg, R. S., Isaacs, R. B., \& Hernandez, E. L. (2018). Identification of shark species in commercial products using DNA barcoding. Fisheries Research, 210, 81-88. doi: 10.1016/j.fishres.2018.10.010

This Article is brought to you for free and open access by the Science and Technology Faculty Articles and Research at Chapman University Digital Commons. It has been accepted for inclusion in Food Science Faculty Articles and Research by an authorized administrator of Chapman University

Digital Commons. For more information, please contact laughtin@chapman.edu. 


\section{Identification of Shark Species in Commercial Products using DNA Barcoding}

\section{Comments}

NOTICE: this is the author's version of a work that was accepted for publication in Fisheries Research. Changes resulting from the publishing process, such as peer review, editing, corrections, structural formatting, and other quality control mechanisms may not be reflected in this document. Changes may have been made to this work since it was submitted for publication. A definitive version was subsequently published in Fisheries Research, volume 210, in 2018. DOI: 10.1016/j.fishres.2018.10.010

The Creative Commons license below applies only to this version of the article.

\section{Creative Commons License}

\section{(c) 1 (1) 90}

This work is licensed under a Creative Commons Attribution-Noncommercial-No Derivative Works 4.0 License.

\section{Copyright}

Elsevier 
1 Title: Identification of shark species in commercial products using DNA barcoding

3 Authors: Rosalee S. Hellberg, Rachel B. Isaacs, and Eduardo L. Hernandez

4

5 Chapman University, Schmid College of Science and Technology, Food Science and Nutrition,

6 One University Drive, Orange, CA 92866

7

$8 *$ Corresponding Author

9 Rosalee S. Hellberg, Ph.D.

10 Chapman University

11 Phone: (714) 628-2811

12 Fax: (714) 289-2041

13 E-mail: hellberg@chapman.edu

14

15

16

17

18

19

20

21

22

23

24 
Abstract

26 Sharks are harvested globally and sold in a variety of commercial products. However,

27 they are particularly vulnerable to overfishing and many species are considered protected or

28 endangered. The objective of this study was to identify species in various commercial shark

29 products and to assess the effectiveness of three different DNA barcoding primer sets. Thirty-

30 five products were collected for this study, including fillets, jerky, soup, and cartilage pills.

31 DNA barcoding of these products was undertaken using two full-length primer sets and one

32 mini-barcode primer set within the cytochrome $c$ oxidase subunit (COI) gene. Successfully

33 sequenced samples were then analyzed and identified to the species level using sequence

34 databases and character-based analysis. When the results of all three primer sets were combined,

$3574.3 \%$ of the products were identified to the species level. Mini-barcoding showed the highest

36 success rate for species identification (54.3\%) and allowed for a wide range of identification

37 capability. Six of the 26 identified products were found to be mislabeled or potentially

38 mislabeled, including samples of shark cartilage pills, shark jerky, and shark fin soup. Six

39 products contained species listed in the Convention on International Trade in Endangered

40 Species of Wild Fauna and Flora (CITES) Appendices and 23 products contained near-

41 threatened, vulnerable or endangered species according to the International Union for the

42 Conservation of Nature (IUCN) Red List. Overall, this study revealed that a combination of

43 DNA barcoding primers can be utilized to identify species in a variety of processed shark

44 products and thereby assist with conservation and monitoring efforts.

45 Keywords: DNA barcoding; elasmobranchs; shark cartilage; shark meat; species identification 


\section{Introduction}

Sharks are harvested worldwide both in targeted fisheries and as bycatch in other fishing

50 operations (Bräutigam, et al., 2015). There is a wide diversity of shark products on the global

51 marketplace, including meat, fins, skin, oil, and cartilage (S. Clarke, 2004; Dent \& Clarke,

52 2015). The greatest consumer demand is for shark meat and fins; however, other shark products

53 are not recorded separately in trade statistics, making them difficult to track. Sharks are

54 particularly vulnerable to overfishing due to their late maturity, relatively long gestation periods,

55 and low fecundity (Bräutigam, et al., 2015). Many populations of sharks and rays are considered

56 threatened or endangered: close to $20 \%$ of the 1,038 species of sharks and rays assessed by the

57 International Union for the Conservation of Nature (IUCN) Red List of Threatened Species have

58 been categorized as Critically Endangered, Endangered, or Vulnerable, and another 12\% have

59 been categorized as Near Threatened (Bräutigam, et al., 2015). Furthermore, the Convention on

60 International Trade in Endangered Species of Wild Fauna and Flora (CITES) has 13 Appendix II

61 listings for sharks and rays, meaning that international trade of these organisms must be

62 controlled through the use of export permits (CITES, 2018). For proper enforcement of CITES,

63 it is essential that customs agents are able to identify these species in globally traded shark

64 products.

65 Intact, unprocessed shark specimens can often be identified to the species level by expert

66 taxonomists using morphological indicators (Hanner, Naaum, \& Shivji, 2016; Marshall \&

67 Barone, 2016). Some shark fins can be identified in this way as well; however, extensive

68 training is required and identification can be problematic due to species that are similar in

69 appearance and the focus on at-risk species. In order to overcome these challenges, a number of

70 DNA-based analyses have been developed for the identification of shark species (reviewed in 
71 Dudgeon, et al., 2012; Hanner, et al., 2016; Rodrigues-Filho, Pinhal, Sondre, \& Vallinoto, 2012).

72 These methods are largely based on the use of polymerase chain reaction (PCR) for amplification

73 of universal or species-specific DNA regions. Several multiplex species-specific PCR assays

74 have been developed to assist with shark conservation efforts and monitoring of international

75 trade (Abercrombie, Clarke, \& Shivji, 2005; Chapman, et al., 2003; S. C. Clarke, Magnussen,

76 Abercrombie, McAllister, \& Shivji, 2006; M. Shivji, et al., 2002; M. S. Shivji, Chapman,

77 Pikitch, \& Raymond, 2005). These studies have revealed trade of shark fins from protected

78 species such as white shark (Carcharodon carcharias) and hammerhead sharks (Sphyrna spp.).

79 While species-specific PCR assays are favored for the rapid identification of known target

80 species, a universal approach, such as DNA barcoding, is advantageous in applications where a

81 wide range of species is possible.

82 DNA barcoding is a sequencing-based technique that utilizes universal primers targeting

83 a short, standardized genetic region for the identification of species (Hebert, Cywinska, Ball, \&

84 DeWaard, 2003). The standard target for DNA barcoding of animal species is a $\sim 650$ bp region

85 of the mitochondrial gene coding for cytochrome $c$ oxidase subunit I (COI). Because of

86 campaigns such as the Fish Barcode of Life Initiative (http://www.fishbol.org/), DNA barcoding

87 is supported by a large database of sequence information to assist with species identification.

88 DNA barcoding of elasmobranchs has been investigated in numerous studies and has proven to

89 be effective in identifying a wide range of species (Bineesh, et al., 2017; Doukakis, et al., 2011;

90 Ward, Holmes, White, \& Last, 2008; Wong, Shivji, \& Hanner, 2009). This method has also

91 been utilized to reveal mislabeling of shark products, as well as trade of threatened and

92 endangered shark species (Asis, Lacsamana, \& Santos, 2016; Barbuto, et al., 2010; Cardeñosa, et

93 al., 2017; Holmes, Steinke, \& Ward, 2009; Liu, Chan, Lin, Hu, \& Chen, 2013; Moore, Almojil, 
94 Harris, Jabado, \& White, 2014; Naaum Amanda \& Hanner, 2015; Sembiring, et al., 2015;

95 Steinke, et al., 2017). However, it can be challenging to recover the full-length DNA barcode

96 from products that have undergone extensive processing as the DNA is often degraded and

97 highly fragmented (Fields, Abercrombie, Eng, Feldheim, \& Chapman, 2015; Shokralla,

98 Hellberg, Handy, King, \& Hajibabaei, 2015). To address this, Fields et al. (2015) developed a

99 mini-barcoding assay for shark species identification that targets a shorter 110-130 bp region

100 within the full-length COI barcode. This assay was shown to be effective in identifying sharks to

101 the species or genus level in $100 \%$ of processed fins tested and $62 \%$ of shark fin soup samples.

102 These results indicate potential use of the shark mini-barcoding assay for species identification in

103 other highly processed shark products, such as shark cartilage supplements.

104 The objective of this study was to use DNA barcoding to identify shark species in

105 commercial products and to compare the effectiveness of three different barcoding methods:

106 shark mini-barcoding, fish full barcoding, and mammalian full barcoding.

\section{2. Materials and Methods}

1082.1 Sample collection

109 A total of 35 commercial shark products were collected for this study. The products were

110 purchased online and from restaurants or retail outlets in Orange and Los Angeles Counties, CA,

111 USA. A variety of products were collected, including shark jerky $(n=3)$, shark fin soup $(n=1)$,

112 shark cartilage pills $(\mathrm{n}=29)$, and fresh or grilled shark fillets $(\mathrm{n}=2)$. Following collection, each

113 product was assigned a sample number and catalogued. Products were then held at their

114 recommended storage temperatures until DNA extraction. DNA was extracted from perishable

115 items within two days of collection.

1162.2 DNA extraction 
Sterile forceps were used to sample tissue from the jerky, soup (ceratotrichia), and fillet

118 samples. Cartilage pills in capsule form were twisted open and the powder was poured directly

119 into a sterile microcentrifuge tube for weighing, while tablets (solid form) were broken up with

120 sterile forceps and then placed into a sterile microcentrifuge tube. DNA was extracted from 25

121 mg of each sample using the DNeasy Blood and Tissue Kit (Qiagen, Valencia, CA), Spin-

122 Column protocol, according to the manufacturer's instructions, with modifications made to the

123 final elution step. DNA was eluted using pre-heated $\left(37^{\circ} \mathrm{C}\right)$ AE buffer at a volume of $60 \mu \mathrm{l}$ for

124 cartilage pill samples and $100 \mu \mathrm{l}$ for all other samples. A reagent blank negative control with no

125 sample added was included with each set of DNA extractions.

1262.3 PCR

127 DNA extracts from each sample underwent PCR using three different primer sets (Table

128 1): a shark mini-barcode primer set (Fields, et al., 2015) and two full-barcode primer sets ('fish

129 full barcode’ and 'mammalian full barcode') used in a previous study on shark species

130 identification (Wong, et al., 2009). With the exception of Shark COI-MINIR, all primers

131 included M13 tails to facilitate DNA sequencing (Table 1). Amplification of shark mini-

132 barcodes was carried out with the following reaction mixture: $25 \mu$ l HotStar Taq Master Mix

133 (2X) (Qiagen), $22 \mu \mathrm{l}$ of molecular-grade sterile water, $1 \mu \mathrm{l}$ of $10 \mu \mathrm{M}$ C_FishF1t1 (Table 1 ), $1 \mu \mathrm{l}$

134 of $10 \mu \mathrm{M}$ Shark COI-MINIR (Table 1), and $1 \mu \mathrm{l}$ of template DNA. Fish and mammalian full

135 barcodes were amplified using the following reaction mixture: $25 \mu$ l HotStar Taq Master Mix

136 (2X) (Qiagen), $23 \mu \mathrm{l}$ of molecular-grade sterile water, $0.5 \mu \mathrm{l}$ of $10 \mu \mathrm{M}$ forward primer cocktail

137 (Table 1 ), $0.5 \mu \mathrm{l}$ of $10 \mu \mathrm{M}$ reverse primer cocktail (Table 1 ), and $1 \mu \mathrm{l}$ of template DNA. A no-

138 template control (NTC) with molecular-grade sterile water instead of DNA was included

139 alongside each set of reactions. PCR was carried out using a Mastercycler nexus Gradient 
140 Thermal Cycler (Eppendorf). The cycling conditions for shark mini-barcoding were: $95^{\circ} \mathrm{C}$ for

$14115 \mathrm{~min} ; 35$ cycles of $94^{\circ} \mathrm{C}$ for $1 \mathrm{~min}, 52^{\circ} \mathrm{C}$ for $1 \mathrm{~min}$, and $72^{\circ} \mathrm{C}$ for $2 \mathrm{~min}$; and a final extension

142 step at $72^{\circ} \mathrm{C}$ for $5 \mathrm{~min}$. The cycling conditions for fish full barcoding were: $95^{\circ} \mathrm{C}$ for $15 \mathrm{~min}$; 35

143 cycles of $94^{\circ} \mathrm{C}$ for $30 \mathrm{~s}, 52^{\circ} \mathrm{C}$ for $40 \mathrm{~s}$, and $72^{\circ} \mathrm{C}$ for $1 \mathrm{~min}$; and a final extension step at $72^{\circ} \mathrm{C}$ for

$14410 \mathrm{~min}$. The cycling conditions for mammalian full barcoding were: $95^{\circ} \mathrm{C}$ for $15 \mathrm{~min} ; 5$ cycles

145 of $94^{\circ} \mathrm{C}$ for $30 \mathrm{~s}, 50^{\circ} \mathrm{C}$ for $40 \mathrm{~s}$, and $72^{\circ} \mathrm{C}$ for $1 \mathrm{~min}$; 35 cycles of $94^{\circ} \mathrm{C}$ for $30 \mathrm{~s}, 55^{\circ} \mathrm{C}$ for $40 \mathrm{~s}$,

146 and $72^{\circ} \mathrm{C}$ for $1 \mathrm{~min}$; and a final extension step at $72^{\circ} \mathrm{C}$ for $10 \mathrm{~min}$.

$147 \quad 2.4$ PCR product confirmation and DNA sequencing

148 Confirmation of PCR products was achieved using 2.0\% agarose E-Gels (Life

149 Technologies, Carlsbad, CA) run on an E-Gel iBase (Life Technologies). A total of $16 \mu \mathrm{l}$ of

150 sterile water and $4 \mu \mathrm{l}$ of PCR product were loaded into each well (Hellberg, Kawalek, Van,

151 Shen, \& Williams-Hill, 2014). Each sample with a visible PCR product on the agarose gel was

152 purified with the QIAquick PCR Purification Kit using a Microcentrifuge (Qiagen), according to

153 the manufacturer's instructions. Purified PCR products were sequenced at the GenScript facility

154 (Piscataway, NJ) with M13 primers. Mini-barcode products were only sequenced in one

155 direction using the forward M13 primers, as described in Fields et al. (2015), while all full-

156 barcoding products were sequenced bi-directionally (Ivanova, Zemlak, Hanner, \& Hebert, 2007).

157 DNA sequencing was performed using the BigDye Terminator v3.1 Cycle Sequencing Kit (Life

158 Technologies) and a 3730xl Genetic Analyzer (Life Technologies).

1592.5 Sequencing results and analysis

160 Raw sequence data was assembled and edited using Geneious R7 [(Biomatters, Ltd.,

161 Auckland, New Zealand) (Kearse, et al., 2012)]. The resulting sequences were trimmed to the

162 appropriate full-barcode (652-658 bp) or mini-barcode (127 bp) regions. Trimmed sequences 
163 with $<2 \%$ ambiguities were queried through the Barcode of Life Database (BOLD) Animal

164 Identification Request Engine (http://www.boldsystems.org/), Species Level Barcodes. Any

165 sequences that could not be identified to the species level in BOLD were next queried in

166 GenBank with the Nucleotide Basic Local Alignment Search Tool (BLASTn;

167 http://blast.ncbi.nlm.nih.gov/Blast.cgi). The top species matches were recorded. Sequences with

168 multiple top species matches and/or secondary matches with $\geq 98 \%$ genetic similarity were next

169 examined using character-based analysis, as described in Wong et al. (2009). The conservation

170 status of each identified species was determined using the IUCN Red List of Threatened Species

171 (http://www.iucnredlist.org/).

\section{3. Results}

173 3.1 Species identification using DNA barcoding

174 DNA barcodes were obtained from at least one primer set for 26 of the 35 commercial

175 shark products tested in this study (Fig. 1). DNA barcodes were recovered from $100 \%$ of the

176 jerky, fillet, and soup products, but only $69 \%$ of the 29 shark cartilage pill samples. The one

177 shark cartilage tablet collected for this study failed PCR with all three primer sets, while 20 of

178 the 28 capsules collected were sequenced by at least one method (Table 2). The shark mini-

179 barcoding primer set was the most successful at identifying shark or other fish species in the

180 products tested, with identification success in 19 of the 35 products (Fig. 1). The mammalian

181 full-barcoding primer set allowed for species identifications in 16 of the 35 products; however,

182 only 10 of the products were identified as shark or other fish species. The remaining six

183 products were identified as wild rice (Oryza rufipogon). The fish full-barcoding primer set was

184 the least successful and was only able to identify species in 3 of the commercial shark products. 
In cases where one sequence matched multiple species with a genetic similarity of $\geq$

186 98\%, character analysis was applied (Wong et al. 2009). The use of character analysis allowed

187 for five of the shark cartilage products (S19, S22, S26, S31, and S35) sequenced across the mini-

188 barcode region to be identified to species level. Character analysis also reduced the number of

189 secondary species matches obtained for three other samples (S21, S27, and S33) sequenced

190 across the mini-barcode region. For example, the mini-barcode sequence for S33 showed a top

191 species match with $99.12 \%$ genetic similarity to spot-tail shark (Carcharhinus sorrah) and a

192 secondary species match to night shark (Carcharhinus signatus) with $98.92 \%$ genetic similarity.

193 However, character analysis revealed that the sequence did not contain one of the nucleotides

194 determined to be diagnostic for night shark.

195 Despite the use of character analysis, eight of the samples sequenced with mini-barcoding

196 continued to have at least one secondary species match with genetic similarity $\geq 98 \%$ (Table 2).

197 This occurred with seven samples containing spot-tail shark and one sample containing blacktip

198 reef shark (Carcharhinus melanopterus). In most cases, the secondary matches were to other

199 Carcharhinus spp. These results are consistent with previous DNA barcoding research that has

200 reported less than 1\% genetic divergence among some members of the Carcharhinus genus

201 (Ward, et al., 2008). Five products sequenced with the shark mini-barcode (S21, S22, S33, S35,

202 and S36) showed equivocal BOLD matches (99.1-100\%) to both spot-tail shark and blacktip

203 shark (Carcharhinus limbatus). Upon further examination, it was found that each sample

204 matched numerous published entries for spot-tail shark and only one entry for blacktip shark,

205 which was an Early-Release sequence and not publicly accessible. When the sequences were

206 queried in GenBank, they all matched spot-tail shark with no equivalent match to blacktip shark.

207 Therefore, these samples were determined to be spot-tail shark. 
None of the shark species detected with mammalian full barcoding showed multiple

209 species matches with $\geq 98 \%$ genetic similarity. All of the samples identified as wild rice showed

210 secondary matches in BOLD to other plant species, such as meadow grass (Poa annua) and

211 ryegrass (Lolium rigidum). The two samples identified as winter skate (Leucoraja ocellata) with

212 full fish barcoding (S05 and S16) each showed a secondary match to one sequence labeled as

213 little skate (Leucoraja erinacea). However, upon further investigation, it was found that this

214 sequence (BOLD Sample ID JF894896) was misidentified and is actually derived from winter

215 skate (Coulson et al. 2011).

216 Mammalian full barcoding generated barcodes for two samples (S09 and S22) that did

217 not show a species match with $\geq 98 \%$ genetic similarity in BOLD. Therefore, these samples

218 were instead identified with GenBank. Sample S09, labeled as “Shark’s Fin Soup,” was

219 identified as delagoa threadfin bream (Nemipterus bipunctatus) with 94\% genetic similarity, and

220 sample S22, a bottle of shark cartilage capsules, was identified as blackspot shark (Carcharhinus

221 sealei) with 96\% genetic similarity. In both cases, the sequence quality was relatively low, with

$222<23 \%$ high quality (HQ) bases. Similarly, the mini-barcode primer set generated a barcode for

223 the shark fin soup sample (S09) with a low HQ score (9.9\%) that did not show a species match

224 with $\geq 98 \%$ genetic similarity in BOLD. The top species match for this sample in GenBank was

225 red bigeye (Priacanthus macracanthus) with 90\% genetic similarity.

2263.2 Mislabeled products

227 Among the 26 samples for which sequences were obtained, 5 samples (19\%) were

228 determined to be mislabeled and one was considered to be potentially mislabeled. The five

229 mislabeled samples claimed to be manufactured in the United States and consisted of one "mako

230 shark” jerky product (S12) identified as thresher shark (Alopias vulpinus); two shark cartilage 
231 pill products (S05, S16) containing undeclared winter skate and no shark species; and two shark

232 cartilage pill products (S19 and S26) containing undeclared rice ingredients in addition to shark

233 species. Another shark cartilage product (S27) that tested positive for rice in addition to shark

234 contained cellulose as an ingredient, which may have been the source of the rice. Therefore, this

235 product was not considered to be mislabeled. The one sample of shark fin soup (S09) tested was

236 determined to be potentially mislabeled due to the detection of teleost fish in the product instead

237 of shark. Of note, the mislabeled jerky product (S12) was obtained from a different brand and

238 online distributor as compared to the correctly labeled sample of mako shark jerky (S02). The

239 two samples containing winter skate were sold under different commercial brand names but were

240 purchased from the same online distributor and originated from the same manufacturer. In

241 contrast, the two shark cartilage pill products identified as containing undeclared rice were

242 purchased from different sellers and originated from different manufacturers.

\section{$243 \quad 3.3$ Conservation status of identified species}

244 Six of the commercial shark products tested in this study were found to contain CITES-

245 listed shark species: silky shark (Carcharhinus falciformis) and thresher sharks [(Alopias spp.)

246 (Table 3)]. However, it should be noted that the CITES listings for these species were not

247 effective until after this study was completed (effective date: 4 October 2017). The three

248 products containing thresher sharks consisted of two jerky samples and one fillet, while silky

249 shark was detected in three shark cartilage pill samples. All 10 species of sharks and skate

250 detected in this study appear on the IUCN Red List of Threatened Species (IUCN, 2017). These

251 species were detected in 23 different commercial products, with some products found to contain

252 multiple species (Table 2). Five of these species are considered to be near threatened, four are

253 considered vulnerable, and one is considered endangered. 


\section{4. Discussion}

\section{4.1 Comparison of DNA barcoding methods}

Using a combination of three DNA barcoding primer sets, species identification

257 (including rice, teleost, and elasmobranch species) was possible in the majority (74.3\%) of

258 commercial shark products tested (Fig. 1). On an individual basis, shark mini-barcoding had the

259 highest identification rate (54.3\%), followed by mammalian full-barcoding (45.7\%), and fish

260 full-barcoding (8.6\%). The three DNA barcoding primer sets proved to be complementary in

261 that they allowed for a wide range of species to be identified. Despite the low success rate of the

262 fish full-barcode primer set, it was the only method that enabled the identification of winter skate

263 in shark cartilage pills (Table 2). Along these lines, the other two primer sets also showed

264 advantages for identification of certain shark species, such as spot-tail shark with mini-barcoding

265 and pelagic thresher (Alopias pelagicus) with mammalian full barcoding. Mammalian full

266 barcoding not only amplified shark species but also resulted in the detection of wild rice in

267 products, indicating the universal nature of this primer set. However, it is important to note that

268 any plant species identifications based on COI DNA barcoding must be verified using a plant-

269 specific DNA barcoding assay, such as that used by Newmaster et al. (2013).

270 The mini-barcode was most effective for detecting species within the shark cartilage pills,

271 demonstrating the benefits of using shorter barcodes on highly processed samples containing

272 degraded DNA. The mammalian full barcode was more effective with lightly processed products

273 likely due to the better DNA quality within these samples. Interestingly, there was only one

274 instance in which all three primer sets were successful with the same product (S32), which was

275 identified as tope shark (Galeorhinus galeus). In three cases (S21, S22, and S33), the use of

276 multiple primer sets allowed for the identification of more than one shark species in shark 
277 cartilage pills. For example, mammalian full barcoding enabled the identification of tope shark

278 in two cartilage pill samples (S21 and S33), while mini-barcoding enabled the identification of

279 spot-tail shark in these products. With regards to CITES-listed species, shark mini-barcoding

280 allowed for the identification of silky shark and thresher shark in products, but not pelagic

281 thresher. On the other hand, mammalian full barcoding allowed for the identification of thresher

282 and pelagic thresher but not silky shark. These results indicate potential complementary uses of

283 these primer sets in identifying CITES-listed species, which require strict monitoring of trade by

284 all member parties.

285 While all jerky, fillet, and soup products were identified to the species level, only $69 \%$ of

286 the shark cartilage pill samples were successfully sequenced and identified. In comparison,

287 Wallace et al. (2012) reported a success rate of only 20\% for DNA barcoding of five animal

288 product capsules. The one capsule (velvet antler) that was successfully sequenced by Wallace et

289 al. (2012) failed with full-length DNA barcoding, but was recovered using a universal mini-

290 barcode primer set. The reduced success with shark cartilage pills in the current study may have

291 been due to several factors, including DNA degradation during processing, the presence of

292 species that could not be amplified with the primer sets used, and/or the use of species mixtures.

293 Because DNA barcoding primers are able to amplify a wide range of species, the presence of

294 multiple species in a single product can lead to an unreadable electropherogram and sequencing

295 failure. The presence of species mixtures may also explain the relatively low genetic similarity

296 (94-96\%) obtained for the top species matches for two samples: a sample of shark fin soup (S09)

297 and a shark cartilage product (S22). Both samples had sequences with relatively low quality

298 scores, which may have been a result of simultaneous amplification of multiple species in a

299 single product. 
301 Potential mislabeling was detected in a variety of product types, including jerky, soup,

302 and shark cartilage supplements (Table 2). Species substitution was the most common type of

303 mislabeling detected, followed by the use of undeclared fillers. As previously mentioned, the

304 one sample of shark fin soup tested was found to be potentially mislabeled due to the detection

305 of teleost fish instead of shark. One explanation for this finding is that the restaurant

306 intentionally did not include shark in the product because it is illegal to sell shark fin in

307 California under A.B. 376, Shark fins (2011). In contrast to these results, a large-scale survey on

308 shark fin soup from U.S. restaurants detected a number of shark species, including tope shark,

309 blue shark (Prionace glauca), and other Carcharhinus spp., with no reports of teleost fish

310 species (Fields, et al., 2015).

311 Among the product types tested, mislabeling was detected most frequently in the shark

312 cartilage supplements. Out of the 20 supplements with a recoverable barcode, $20 \%$ were found

313 to be mislabeled. Similarly, Wallace et al. (2012) reported 2 of 10 shark natural health products

314 collected in North America to be mislabeled, including one sample of shark bones and one dried,

315 shredded shark fin. Undeclared rice was detected in two of the shark cartilage products tested in

316 the current study (S19 and S26). Rice is a common filler used in dietary supplements; however,

317 additional testing of the shark cartilage products using plant-specific barcodes would be needed

318 to confirm this detection. The presence of undeclared fillers has previously been reported in

319 herbal products sold in North America (Newmaster, et al., 2013). In comparison to the current

320 study, which found undeclared fillers in $7 \%$ of shark cartilage supplements tested, Newmaster et

321 al. (2013) reported the presence of undeclared fillers (rice or wheat) in $21 \%$ of herbal products 
322 tested. The presence of undeclared fillers such as these in a product can be a health risk for

323 individuals with allergies.

324 Three bottles of shark cartilage pills were found to contain rice, with no shark species

325 detected in the products (S08, S18, and S30). However, all of these samples included rice flour

326 or rice powder in the ingredient list. Due to the possibility that these products contained shark

327 DNA that could not be amplified by the methods used in this study, they were not considered to

328 be mislabeled. One of the samples (S30) specifically stated that it contained dogfish shark,

329 which is considered an acceptable market name for a number of species, including Squalus spp.

330 (FDA, 2016). Dogfish from the Squalus genus was detected previously with the shark mini-

331 barcoding method in a sample of shark fin soup (Fields, et al., 2015) and the authors predicted

332 that the shark mini-barcoding assay described in their study would be capable of amplifying all

333 or most shark species. However, the use of fillers, such as rice, can be problematic for DNA

334 sequencing, as this can result in an unreadable mixed signal due to the simultaneous

335 amplification of multiple species.

$336 \quad 4.3$ Conservation issues

337 This study revealed the presence of near threatened, vulnerable, and endangered

338 elasmobranch species on the U.S. commercial marketplace. Many of these species are

339 considered to be of concern because they are under heavy fishing pressure, targeted by

340 unmanaged and unreported fisheries, and known to be exploited for their fins and meat (IUCN,

341 2017). However, it should be noted that sustainable fisheries do exist for some of these species

342 in specific geographic regions. For example, the National Oceanic and Atmospheric

343 Administration (NOAA) FishWatch considers U.S. wild-caught shortfin mako (Isurus

344 oxyrinchus) to be sustainably managed and responsibly harvested (NOAA, 2017). 
Winter skate, which was found in two products, was the only species detected in this

346 study that is considered to be endangered by IUCN. This species inhabits shelf waters of the

347 northwest Atlantic Ocean and it is primarily harvested for use in skate wings (Kulka, Sulikowski,

348 \& Gedamke, 2009). The IUCN considers this species to be endangered globally due to the

349 observance of substantial declines in major areas of the species' range. However, according to

350 NOAA FishWatch, winter skate that is wild-caught in the United States is considered to be

351 sustainably managed and responsibly harvested (NOAA, 2017).

352 The most common species detected varied depending on the type of commercial product.

353 For example, all of the jerky, steak, and fillet samples were found to contain shortfin mako,

354 pelagic thresher or thresher. All three species are considered vulnerable according to the IUCN

355 Red List and the latter two are CITES-listed. On the other hand, the majority of shark cartilage

356 pills contained spot-tail shark, a near threatened species, with other commonly detected species

357 being tope shark (vulnerable) and silky shark (near threatened and CITES listed). Less

358 frequently detected species include winter skate and two near threatened species (blue shark and

359 blackspot shark). Previous studies reported the presence of blue shark in a sample of dried shark

360 cartilage (Wallace, et al., 2012) and basking shark (Cetorhinus maximus) in a cartilage pill

361 product (Hoelzel, 2001). Similar to the results of the current study, Fields et al. (2015) primarily

362 detected requiem sharks (Carcharhinus spp.) followed by tope (school) sharks, blue sharks, and

363 spot-tail shark in dried processed fin samples from Hong Kong. These results support earlier

364 reports that shark cartilage is utilized as a by-product of existing shark fisheries (Rose, 1996).

365 Currently, shark cartilage is not separately recorded as part of global trade statistics and there is a

366 lack of information on the quantities being traded and the exact species that are used.

\section{5. Conclusions}


369 in commercial shark products. The three primer sets examined in this study proved to be

370 complementary in their ability to identify a range of elasmobranch species. Shark mini-

371 barcoding was found to be the most successful assay for identification of shark species in highly

372 processed shark cartilage pills, while mammalian full barcoding was the most effective at

373 identifying species in lightly processed products, such as fillets and jerky. This study also

374 revealed the ability of these assays to detect trade of threatened and endangered species in

375 commercial shark products, including several CITES-listed species, thereby facilitating

376 conservation efforts and monitoring of international trade. While many of the shark species

377 detected in this study have been reported in the global shark fin trade, this is the most extensive

378 report to-date of shark species in commercial shark cartilage supplements. Many of the species

379 identified in these supplements are known for being targeted in the commercial shark fin trade

380 and the results indicate that they are also being used for shark cartilage production. Furthermore,

381 this is the first report of the use of winter skate as a substitute for shark species in cartilage pill

382 supplements. Although DNA barcoding was successful with lightly processed products,

383 detection of species in shark cartilage pills was relatively challenging and may benefit from

384 further optimization.

385 Acknowledgements

386 This work was supported in part by a grant from the National Science Foundation, Division of

387 Earth Sciences, NSF-EAR \#1359500. Additional funding support was received from Chapman

388 University, Office of the Chancellor. These funding entities were not involved with the design

389 or execution of the study.

390 References 
Abercrombie, D. L., Clarke, S. C., \& Shivji, M. S. (2005). Global-scale genetic identification of hammerhead sharks: Application to assessment of the international fin trade and law enforcement. Conserv. Gen., 6, 775-788.

Asis, A. M. J. M., Lacsamana, J. K. M., \& Santos, M. D. (2016). Illegal trade of regulated and protected aquatic species in the Philippines detected by DNA barcoding. Mitochondrial DNA Part A, 27(1), 659-666.

Barbuto, M., Galimberti, A., Ferri, E., Labra, M., Malandra, R., Galli, P., \& Casiraghi, M. (2010). DNA barcoding reveals fraudulent substitutions in shark seafood products: The Italian case of "palombo" (Mustelus spp.). Food Res. Int., 43(1), 376-381.

Bineesh, K. K., Gopalakrishnan, A., Akhilesh, K. V., Sajeela, K. A., Abdussamad, E. M., Pillai, N. G. K., Basheer, V. S., Jena, J. K., \& Ward, R. D. (2017). DNA barcoding reveals species composition of sharks and rays in the Indian commercial fishery. Mitochondrial DNA Part A, 28(4), 458-472.

Bräutigam, A., Callow, M., Campbell, I. R., Camhi, M. D., Cornish, A. S., Dulvy, N. K., Fordham, S. V., Fowler, S. L., Hood, A. R., McClennen, C., Reuter, E. L., Sant, G., Simpfendorfer, C. A., \& Welch, D. J. (2015). Global Priorities for Conserving Sharks and Rays: A 2015-2025 Strategy.

Cardeñosa, D., Fields, A., Abercrombie, D., Feldheim, K., Shea, S. K. H., \& Chapman, D. D. (2017). A multiplex PCR mini-barcode assay to identify processed shark products in the global trade. PLoS ONE, 12(10), e0185368.

Chapman, D. D., Abercrombie, D. L., Douady, C. J., Pikitch, E. K., Stanhope, M. J., \& Shivji, M. S. (2003). A streamlined, bi-organelle, multiplex PCR approach to species 
identification: Application to global conservation and trade monitoring of the great white

414 shark, Carcharodon carcharias. Conserv. Gen., 4, 415-425.

415 CITES. (2018). Convention on International Trade in Endangered Species of Wild Fauna and

$416 \quad$ Flora. https://www.cites.org/eng (Accessed 7/10/2018).

417 Clarke, S. (2004). Shark Product Trade in Hong Kong and Mainland China and Implementation

418 of the CITES Shark Listings. Hong Kong, China: TRAFFIC East Asia.

419 Clarke, S. C., Magnussen, J. E., Abercrombie, D. L., McAllister, M. K., \& Shivji, M. S. (2006).

420 Identification of shark species composition and proportion in the Hong Kong shark fin

421 market based on molecular genetics and trade records. Conserv. Biol., 20(1), 201-211.

422 Dent, F., \& Clarke, S. (2015). State of the Global Market for Shark Products. FAO Fisheries and

423 Aquaculture Technical Paper No. 590. Rome, FAO. 187 pp.

424 Doukakis, P., Hanner, R., Shivji, M., Bartholomew, C., Chapman, D., Wong, E., \& Amato, G.

425 (2011). Applying genetic techniques to study remote shark fisheries in northeastern

426 Madagascar. Mitochondrial DNA, 22(sup1), 15-20.

427 Dudgeon, C. L., Blower, D. C., Broderick, D., Giles, J. L., Holmes, B. J., Kashiwagi, T., Krück,

428 N. C., Morgan, J. A. T., Tillett, B. J., \& Ovenden, J. R. (2012). A review of the

429 application of molecular genetics for fisheries management and conservation of sharks

$430 \quad$ and rays. J. Fish Biol., 80(5), 1789-1843.

431 FDA. (2016). The Seafood List. https://www.accessdata.fda.gov/scripts/fdcc/?set=seafoodlist (Accessed 7/26/17).

433 Fields, A. T., Abercrombie, D. L., Eng, R., Feldheim, K., \& Chapman, D. D. (2015). A novel 434 mini-DNA barcoding assay to identify processed fins from internationally protected shark $435 \quad$ species. PLoS ONE, 10(2), e0114844. 
Hanner, R. H., Naaum, A. M., \& Shivji, M. S. (2016). DNA-based authentication of shark products and implications for conservation and management. In R. H. Hanner \& A. M. Nauum (Eds.), Seafood authenticity and traceability: A DNA-based perspective (pp. 171179). San Diego, CA, USA: Academic Press/Elsevier.

Hebert, P. D. N., Cywinska, A., Ball, S. L., \& DeWaard, J. R. (2003). Biological identifications through DNA barcodes. Proc. R. Soc. B Biol. Sci., 270(1512), 313-321.

Hellberg, R. S., Kawalek, M. D., Van, K. T., Shen, Y., \& Williams-Hill, D. M. (2014). Comparison of DNA extraction and PCR setup methods for use in high-throughput DNA barcoding of fish species. Food Anal. Method, 7, 1950-1959.

Hoelzel, A. R. (2001). Shark fishing in fin soup. Conserv. Gen., 2(1), 69-72.

Holmes, B. H., Steinke, D., \& Ward, R. D. (2009). Identification of shark and ray fins using DNA barcoding. Fisheries Res., 95, 280-288.

IUCN. (2017). The IUCN Red List of Threatened Species. Version 2017-1. http://www.iucnredlist.org (Accessed 7/26/17).

Ivanova, N. V., Zemlak, T. S., Hanner, R. H., \& Hebert, P. D. N. (2007). Universal primer cocktails for fish DNA barcoding. Mol. Ecol. Notes, 7, 544-548.

Kearse, M., Moir, R., Wilson, A., Stones-Havas, S., Cheung, M., Sturrock, S., Buxton, S., Cooper, A., Markowitz, S., Duran, C., Thierer, T., Ashton, B., Meintjes, P., \& Drummond, A. (2012). Geneious Basic: An integrated and extendable desktop software platform for the organization and analysis of sequence data. Bioinformatics, 28(12), 1647-1649.

Kulka, D. W., Sulikowski, J., \& Gedamke, T. (2009). Leucoraja ocellata. The IUCN Red List of Threatened Species 2009: e.T161631A5468670. 

7/26/17).

461 Liu, S.-Y. V., Chan, C.-L. C., Lin, O., Hu, C.-S., \& Chen, C. A. (2013). DNA barcoding of shark meats identify species composition and CITES-listed species from the markets in Taiwan. PLoS ONE, 8(11), e79373.

464 Marshall, L. J., \& Barone, M. (2016). SharkFin Guide: identifying sharks from their fins. FAO, 465 Rome, Italy.

466 Messing, J. (1983). New M13 vectors for cloning. Methods Enzymol., 101, 20-79.

467 Moore, A. B. M., Almojil, D., Harris, M., Jabado, R. W., \& White, W. T. (2014). New biological 468 data on the rare, threatened shark Carcharhinus leiodon (Carcharhinidae) from the 469 Persian Gulf and Arabian Sea. Mar. Freshwater Res., 65(4), 327-332.

470 Naaum Amanda, M., \& Hanner, R. (2015). Community engagement in seafood identification using DNA barcoding reveals market substitution in Canadian seafood. DNA Barcodes,

473 Newmaster, S. G., Grguric, M., Shanmughanandhan, D., Ramalingam, S., \& Ragupathy, S.

474 (2013). DNA barcoding detects contamination and substitution in North American herbal products. BMC Medicine, 11(1), e222.

476 NOAA. (2017). FishWatch. https://www.fishwatch.gov/ (Accessed 7/26/17).

477 Rodrigues-Filho, L. F., Pinhal, D., Sondre, D., \& Vallinoto, M. (2012). Shark DNA forensics: 478 Applications and impacts on genetic diversity In M. Caliskan (Ed.), Analysis of genetic 479 variation in animals (pp. 269-286). Rijeka, Croatia: InTech.

480 Rose, D. (1996). An Overview of World Trade in Sharks and Other Cartilaginous Fishes. A 481 TRAFFIC Network Report. 106 p. 
482 Sembiring, A., Pertiwi, N. P. D., Mahardini, A., Wulandari, R., Kurniasih, E. M., Kuncoro, A.

483 W., Cahyani, N. K. D., Anggoro, A. W., Ulfa, M., Madduppa, H., Carpenter, K. E., Barber, P. H., \& Mahardika, G. N. (2015). DNA barcoding reveals targeted fisheries for endangered sharks in Indonesia. Fisheries Res., 164, 130-134.

Shivji, M., Clarke, S., Pank, M., Natanson, L., Kohler, N., \& Stanhope, M. (2002). Genetic identification of pelagic shark body parts for conservation and trade monitoring. Conserv.

Shivji, M. S., Chapman, D. D., Pikitch, E. K., \& Raymond, P. W. (2005). Genetic profiling reveals illegal international trade in fins of the great white shark, Carcharodon carcharias. Conserv. Gen., 6, 1035-1039.

492 Shokralla, S., Hellberg, R. S., Handy, S. M., King, I., \& Hajibabaei, M. (2015). A DNA minibarcoding system for authentication of processed fish products. Sci. Rep., 5, Article number: 15894.

Steinke, D., Bernard, A. M., Horn, R. L., Hilton, P., Hanner, R., \& Shivji, M. S. (2017). DNA analysis of traded shark fins and mobulid gill plates reveals a high proportion of species

498 Wallace, L. J., Boilard, S. M. A. L., Eagle, S. H. C., Spall, J. L., Shokralla, S., \& Hajibabaei, M. (2012). DNA barcodes for everyday life: Routine authentication of Natural Health Products. Food Res. Int., 49(1), 446-452.

501 Ward, R. D., Holmes, B. H., White, W. T., \& Last, P. R. (2008). DNA barcoding Australasian 502 chondrichthyans: results and potential uses in conservation. Mar. Freshwater Res., 59(1), 503 57-71. 
504 Wong, E. H. K., Shivji, M. S., \& Hanner, R. H. (2009). Identifying sharks with DNA barcodes:

505 assessing the utility of a nucleotide diagnostic approach. Mol. Ecol. Resour., 9, 243-256.

506 
Table 1. Details for the PCR primer sets and M13 tails used in this study.

\begin{tabular}{|c|c|c|c|c|c|c|}
\hline Primer set & $\begin{array}{l}\text { Primer } \\
\text { cocktail }\end{array}$ & Primer name & Primer sequence (5’'-3') ${ }^{\mathrm{a}}$ & $\begin{array}{l}\text { Ratio in } \\
\text { Cocktail }\end{array}$ & $\begin{array}{l}\text { Barcode } \\
\text { length }\end{array}$ & Reference \\
\hline \multirow[t]{3}{*}{$\begin{array}{l}\text { Shark mini- } \\
\text { barcode }\end{array}$} & C_FishF1t1 & VF2_t1 & $\begin{array}{l}\text { TGTAAAACGACGGCCAGTCAACCAACCACAA } \\
\text { AGACATTGGCAC }\end{array}$ & 1 & 127 bp & $\begin{array}{l}\text { Ivanova, et al. } \\
\text { (2007) }\end{array}$ \\
\hline & & FishF2_t1 & $\begin{array}{l}\text { TGTAAAACGACGGCCAGTCGACTAATCATAA } \\
\text { AGATATCGGCAC }\end{array}$ & 1 & & \\
\hline & N/A & $\begin{array}{l}\text { Shark COI- } \\
\text { MINIR }\end{array}$ & AAGATTACAAAAGCGTGGGC & N/A & & $\begin{array}{l}\text { Fields, et al. } \\
\text { (2015) }\end{array}$ \\
\hline \multirow[t]{4}{*}{$\begin{array}{l}\text { Fish full } \\
\text { barcode }\end{array}$} & C_FishF1t1 & VF2_t1 & $\begin{array}{l}\text { TGTAAAACGACGGCCAGTCAACCAACCACAA } \\
\text { AGACATTGGCAC }\end{array}$ & 1 & 652 bp & $\begin{array}{l}\text { Ivanova, et al. } \\
\text { (2007) }\end{array}$ \\
\hline & & FishF2_t1 & $\begin{array}{l}\text { TGTAAAACGACGGCCAGTCGACTAATCATAA } \\
\text { AGATATCGGCAC }\end{array}$ & 1 & & \\
\hline & C_FishR1t1 & FishR2_t1 & $\begin{array}{l}\text { CAGGAAACAGCTATGACACTTCAGGGTGACC } \\
\text { GAAGAATCAGAA }\end{array}$ & 1 & & \\
\hline & & FR1d_t1 & $\begin{array}{l}\text { CAGGAAACAGCTATGACACCTCAGGGTGTCC } \\
\text { GAARAAYCARAA }\end{array}$ & 1 & & \\
\hline \multirow[t]{2}{*}{$\begin{array}{l}\text { Mammalian } \\
\text { full barcode }\end{array}$} & C_VF1LFt1 & LepF1_t1 & $\begin{array}{l}\text { TGTAAAACGACGGCCAGTATTCAACCAATCA } \\
\text { TAAAGATATTGG }\end{array}$ & 1 & 658 bp & $\begin{array}{l}\text { Ivanova, et al. } \\
\text { (2007) }\end{array}$ \\
\hline & & VF1_t1 & $\begin{array}{l}\text { TGTAAAACGACGGCCAGTTCTCAACCAACCA } \\
\text { CAAAGACATTGG }\end{array}$ & 1 & & \\
\hline
\end{tabular}




\begin{tabular}{|c|c|c|c|c|c|c|}
\hline & & VF1d_t1 & TGTAAAACGACGGCCAGTTCTCAACCAACCA & 1 & & \\
\hline & & & CAARGAYATYGG & & & \\
\hline & & VF1i_t1 & TGTAAAACGACGGCCAGTTCTCAACCAACCA & 3 & & \\
\hline & & & IAAIGAIATIGG & & & \\
\hline & C_VR1LRt1 & LepRI_t1 & CAGGAAACAGCTATGACTAAACTTCTGGATG & 1 & & \\
\hline & & & TCCAAAAAATCA & & & \\
\hline & & VR1d_t1 & CAGGAAACAGCTATGACTAGACTTCTGGGTG & 1 & & \\
\hline & & & GCCRAARAAYCA & & & \\
\hline & & VR1_t1 & CAGGAAACAGCTATGACTAGACTTCTGGGTG & 1 & & \\
\hline & & & GCCAAAGAATCA & & & \\
\hline & & VR1i_t1 & CAGGAAACAGCTATGACTAGACTTCTGGGTG & 3 & & \\
\hline & & & ICCIAAIAAICA & & & \\
\hline M13 & N/A & M13F (-21) & TGTAAAACGACGGCCAGT & N/A & N/A & Messing (1983) \\
\hline & N/A & M13R $(-27)$ & CAGGAAACAGCTATGAC & N/A & $\mathrm{N} / \mathrm{A}$ & \\
\hline
\end{tabular}

a Shaded portions indicate M13 tails 
Table 2. Species identified in the 26 commercial shark products successfully sequenced by at least one of the primer sets tested in this study. Products found to be mislabeled or potentially mislabeled are shown in boldface.

\begin{tabular}{|c|c|c|c|c|}
\hline \multirow{2}{*}{$\begin{array}{l}\text { Sample } \\
\text { ID }\end{array}$} & \multirow[t]{2}{*}{ Sample description } & \multicolumn{3}{|c|}{ Identified species } \\
\hline & & Fish full barcode & Mammalian full barcode & Shark mini-barcode \\
\hline S01 & Mako shark steak, grilled & Failed PCR & Shortfin mako (Isurus oxyrinchus) & Shortfin mako (Isurus oxyrinchus) \\
\hline S02 & Mako shark jerky & Failed PCR & Shortfin mako (Isurus oxyrinchus) & Shortfin mako (Isurus oxyrinchus) \\
\hline S05 & Shark cartilage capsules & $\begin{array}{l}\text { Winter skate } \\
\text { (Leucoraja ocellata) }^{a}\end{array}$ & Failed PCR & Failed sequencing \\
\hline S08 & Shark cartilage capsules & Failed PCR & Wild rice (Oryza rufipogon) ${ }^{\mathrm{a}}$ & Failed PCR \\
\hline S09 & Shark's fin soup & Failed sequencing & $\begin{array}{l}\text { Delagoa threadfin bream } \\
\text { (Nemipterus bipunctatus) }^{\text {b }}\end{array}$ & $\begin{array}{l}\text { Red bigeye (Priacanthus } \\
\text { macracanthus) }\end{array}$ \\
\hline S10 & $\begin{array}{l}\text { Thresher shark fillet, } \\
\text { fresh/frozen }\end{array}$ & Failed PCR & Pelagic thresher (Alopias pelagicus) & Failed PCR \\
\hline S11 & Shark jerky & Failed PCR & Pelagic thresher (Alopias pelagicus) & Failed PCR \\
\hline S12 & Mako shark jerky & Failed PCR & Thresher (Alopias vulpinus) & Thresher (Alopias vulpinus) \\
\hline S13 & Shark cartilage capsules & Failed PCR & Failed PCR & $\begin{array}{l}\text { Spot-tail shark (Carcharhinus } \\
\text { sorrah) }^{\mathrm{a}}\end{array}$ \\
\hline S14 & Shark cartilage capsules & Failed PCR & Failed sequencing & $\begin{array}{l}\text { Spot-tail shark (Carcharhinus } \\
\text { sorrah) }^{\mathrm{a}}\end{array}$ \\
\hline S16 & Shark cartilage capsules & 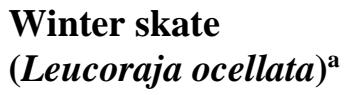 & Failed sequencing & Failed PCR \\
\hline S17 & Shark cartilage capsules & Failed PCR & Failed PCR & Tope shark (Galeorhinus galeus) \\
\hline S18 & Shark cartilage capsules & Failed PCR & Wild rice (Oryza rufipogon) ${ }^{\mathrm{a}}$ & Failed PCR \\
\hline S19 & Shark cartilage capsules & Failed PCR & Wild rice (Oryza rufipogon) $^{\mathrm{a}}$ & $\begin{array}{l}\text { Silky shark (Carcharhinus } \\
\text { falciformis) }^{\mathrm{c}}\end{array}$ \\
\hline $\mathrm{S} 21$ & Shark cartilage capsules & Failed sequencing & Tope shark (Galeorhinus galeus) & $\begin{array}{l}\text { Spot-tail shark (Carcharhinus } \\
\text { sorrah) }\end{array}$ \\
\hline $\mathrm{S} 22$ & Shark cartilage capsules & Failed sequencing & $\begin{array}{l}\text { Blackspot shark (Carcharhinus } \\
\text { sealei) }\end{array}$ & $\begin{array}{l}\text { Spot-tail shark (Carcharhinus } \\
\text { sorrah) }\end{array}$ \\
\hline S23 & Shark cartilage capsules & Failed PCR & Failed sequencing & $\begin{array}{l}\text { Spot-tail shark (Carcharhinus } \\
\text { sorrah) }^{\mathrm{a}}\end{array}$ \\
\hline
\end{tabular}




\begin{tabular}{|c|c|c|c|c|}
\hline S26 & Shark cartilage capsules & Failed PCR & Wild rice (Oryza rufipogon) $^{\mathrm{a}}$ & $\begin{array}{l}\text { Silky shark (Carcharhinus } \\
\text { falciformis) }^{\mathrm{c}}\end{array}$ \\
\hline S27 & Shark cartilage capsules & Failed sequencing & Wild rice (Oryza rufipogon) ${ }^{\mathrm{a}}$ & $\begin{array}{l}\text { Blacktip reef shark (Carcharhinus } \\
\text { melanopterus) }\end{array}$ \\
\hline S28 & Shark cartilage capsules & Failed sequencing & Failed sequencing & Blue shark (Prionace glauca) \\
\hline S30 & $\begin{array}{l}\text { Shark cartilage capsules } \\
\text { with dogfish shark }\end{array}$ & Failed PCR & Wild rice (Oryza rufipogon) ${ }^{\mathrm{a}}$ & Failed PCR \\
\hline S31 & Shark cartilage capsules & Failed PCR & Failed sequencing & $\begin{array}{l}\text { Silky shark (Carcharhinus } \\
\text { falciformis) }^{\mathrm{c}}\end{array}$ \\
\hline S32 & Shark cartilage capsules & $\begin{array}{l}\text { Tope shark (Galeorhinus } \\
\text { galeus) }\end{array}$ & Tope shark (Galeorhinus galeus) & Tope shark (Galeorhinus galeus) \\
\hline S33 & $\begin{array}{l}\text { Pacific Ocean shark } \\
\text { cartilage capsules }\end{array}$ & Failed sequencing & Tope shark (Galeorhinus galeus) & $\begin{array}{l}\text { Spot-tail shark (Carcharhinus } \\
\text { sorrah) }^{\mathrm{a}}\end{array}$ \\
\hline S35 & Shark cartilage capsules & Failed PCR & Failed PCR & $\begin{array}{l}\text { Spot-tail shark (Carcharhinus } \\
\text { sorrah) }^{\text {ac }}\end{array}$ \\
\hline S36 & Shark cartilage capsules & Failed PCR & Failed PCR & $\begin{array}{l}\text { Spot-tail shark (Carcharhinus } \\
\text { sorrah) }^{\mathrm{a}}\end{array}$ \\
\hline
\end{tabular}

a Sequence had secondary species matches with $\geq 98 \%$ genetic similarity that could not be ruled out with character analysis ${ }^{\mathrm{b}}$ Top species match was $<98 \%$ genetic similarity

'Species identification included the use of character analysis 
Table 3. Conservation status of the elasmobranch species detected in commercial products tested in this study.

\begin{tabular}{lllll}
\hline Elasmobranch species & Common name & CITES Listing & IUCN Red List status & $\begin{array}{l}\text { Number of products } \\
\text { containing species }\end{array}$ \\
\hline $\begin{array}{llll}\text { Leucoraja ocellata } \\
\text { Alopias pelagicus }\end{array}$ & Winter skate & Not listed & Endangered & 2 \\
Alopias vulpinus & Pelagic thresher & Appendix II (October 2017) & Vulnerable & 2 \\
Galeorhinus galeus & Thresher & Appendix II (October 2017) & Vulnerable & 1 \\
Isurus oxyrinchus & Tope shark & Not listed & Vulnerable & 4 \\
Carcharhinus sorrah & Shortfin mako & Not listed & Vulnerable & 2 \\
Carcharhinus falciformis & Spot-tail shark & Not listed & Near Threatened & 8 \\
Carcharhinus & Blilky shark & Appendix II (October 2017) & Near Threatened & 3 \\
melanopterus & shark & Not listed & Near Threatened & 1 \\
Prionace glauca & Blue shark & Not listed & Near Threatened & 1 \\
Carcharhinus sealei & Blackspot shark & Not listed & Near Threatened & 1 \\
\hline
\end{tabular}




\section{Figure caption}

Figure 1. Percentage of commercial shark products $(n=35)$ identified through DNA barcoding with three different primer sets. 